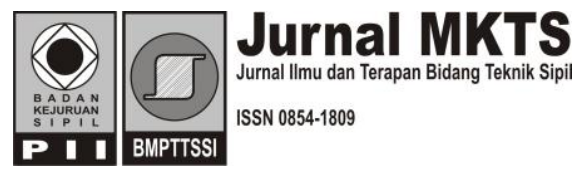

\title{
Panen Air Hujan di Kampus Universitas Diponegoro
}

\author{
Faisal Nurrohman \\ Jurusan Teknik Sipil, Fakultas Teknik, Universitas Diponegoro \\ J1.Prof. Soedarto, SH, Tembalang, Semarang 50275 \\ E-mail: faisalnurr22@gmail.com \\ Satria Waskita Eka Paksi \\ Jurusan Teknik Sipil, Fakultas Teknik, Universitas Diponegoro \\ Jl.Prof. Soedarto, SH, Tembalang, Semarang 50275 \\ E-mail: satria.waskita.e.p@gmail.com \\ Sri Sangkawati Sachro \\ Jurusan Teknik Sipil, Fakultas Teknik, Universitas Diponegoro \\ Jl.Prof. Soedarto, SH, Tembalang, Semarang 50275 \\ E-mail: srisangkawati@gmail.com

\section{Sugiyanto} \\ Jurusan Teknik Sipil, Fakultas Teknik, Universitas Diponegoro \\ Jl.Prof. Soedarto, SH, Tembalang, Semarang 50275 \\ E-mail: sugi.pandakl@gmail.com
}

\begin{abstract}
The design of rainwater harvesting is planned for alternative water source in Universitas Diponegoro area and hopefully it can reduce the use of groundwater as the main source water to fill the demand of water in Universitas Diponegoro Tembalang area. The use of groundwater to fill the water demand in Universitas Diponegoro Campus for years 2014/2015 of 2.23 lt/dt it more than the optimum discharge are allowable to take the water wells is equal to 0.2-1 lt/dt. Based on that the planning of the rainwater harvesting building is made of with a volume of $245 \mathrm{~m}^{3}$ with a dimensions of $7 \mathrm{~m} \times 7 \mathrm{~m} \times 5 \mathrm{~m}$ and dimensions of infiltration wells with a diameter of 1.5 and depth of $3 \mathrm{~m}$. Planning of the rain water harvesting in the Universitas Diponegoro Tembalang area the cost of Rp 275,465,000,- with the process of work for 29 days.
\end{abstract}

Keywords: Rainwater harversting, Cistern, Infiltration well.

\begin{abstract}
Abstrak
Perencanaan panen air hujan direncanakan sebagai sumber air alternatif pada kawasan Universitas Diponegoro sehingga diharapkan adanya pengurangan penggunaan air tanah sebagai sumber utama pemenuhan kebutuhan air pada wilayah Universitas Diponegoro Tembalang. Penggunaan air tanah untuk memenuhi kebutuhan air pada wilayah Kampus Universitas Diponegoro untuk tahun 2014/2015 sebesar 2,23 lt/dt melebihi debit optimum pengambilan air sumur yang diijinkan yaitu sebesar 0,2-1 lt/dt. Berdasarkan hal tersebut dibuat perencanaan bangunan air hujan dengan volume $245 \mathrm{~m}^{3}$ dengan dimensi $7 m \times 7 m \times 5 m$ dan dimensi sumur resapan dengan diameter 1,5 m dan kedalaman $3 \mathrm{~m}$. Perencanaan bangunan panen air hujan pada kawasan Universitas Diponegoro Tembalang memakan biaya sebesar Rp 275.465.000,- dengan proses pekerjaan selama 29 hari.
\end{abstract}

Kata-kata Kunci: Panen air hujan, Cistern, Sumur resapan. 


\section{Pendahuluan}

Pembangunan Kampus Universitas Diponegoro di Tembalang membawa dampak yang besar terhadap perubahan tata guna lahan. Pada awalnya, kawasan sekitar Kampus Universitas Diponegoro di Tembalang sebagian besar merupakan daerah resapan air. Namun, seiring dengan perkembangan Kampus Universitas Diponegoro dan semakin meningkatnya kebutuhan akomodasi untuk mahasiswa, menjadikan kawasan sekitar kampus mengalami perubahan tata guna lahan menjadi kawasan terbangun berupa permukiman.

Luas lahan terbuka Kampus Universitas Diponegoro Tembalang sebelum adanya pembangunan yaitu sebesar $1.352 .054 \mathrm{~m}^{2}$. Dalam masterplan pembangunan Kampus Universitas Diponegoro Tembalang dijelaskan bahwa luas total pembangunan gedung kampus beserta bangunan penunjang seperti lapangan basket, lahan parkir dan jalan aspal sebesar $877.742 \mathrm{~m}^{2}$ dan sisanya sebesar $202.000 \mathrm{~m}^{2}$ direncanakan untuk lahan terbuka. Pada tahun 2013 gedung kampus yang telah dibangun seluas $668.347 \mathrm{~m}^{2}$ sehingga dapat diketahui persentase perubahan lahan menjadi lahan terbangun sebesar $43 \%$ dari lahan terbuka keseluruhan. Hal tersebut menunjukkan berkurangnya lahan hijau pada wilayah dibangunnya Kampus Universitas Diponegoro Tembalang.
Hal tersebut mengakibatkan berkurangnya lahan resapan air yang berakibat pada meningkatnya volume aliran limpasan air permukaan sehingga infiltrasi berkurang. Keadaan tersebut dapat mengurangi jumlah air tanah yang merupakan sumber air tawar sebagai sumber air bersih. Selain itu, pertambahan jumlah populasi yang didukung dengan tindakan konsumtif yang berlebihan serta kurang kepedulian terhadap lingkungan juga menyebabkan berkurangnya air bersih.

Dengan latar belakang tersebut, perlu dilakukan pengkajian tentang sistem panen air hujan dan perencanaan panen air hujan di Kampus Universitas Diponegoro sebagai sumber air alternatif dan sebagai kegiatan konservasi.

Tujuan studi ini adalah untuk menganalisis potensi dan merencanakan penggunaan air hujan sebagai sumber air alternatif untuk mengurangi penggunaan air tanah dalam usaha kegiatan konservasi di wilayah Kampus Universitas Diponegoro.

\section{Metode Perencanaan}

Langkah-langkah perencanaan panen air hujan disajikan dalam bagan alir pada Gambar 1 .

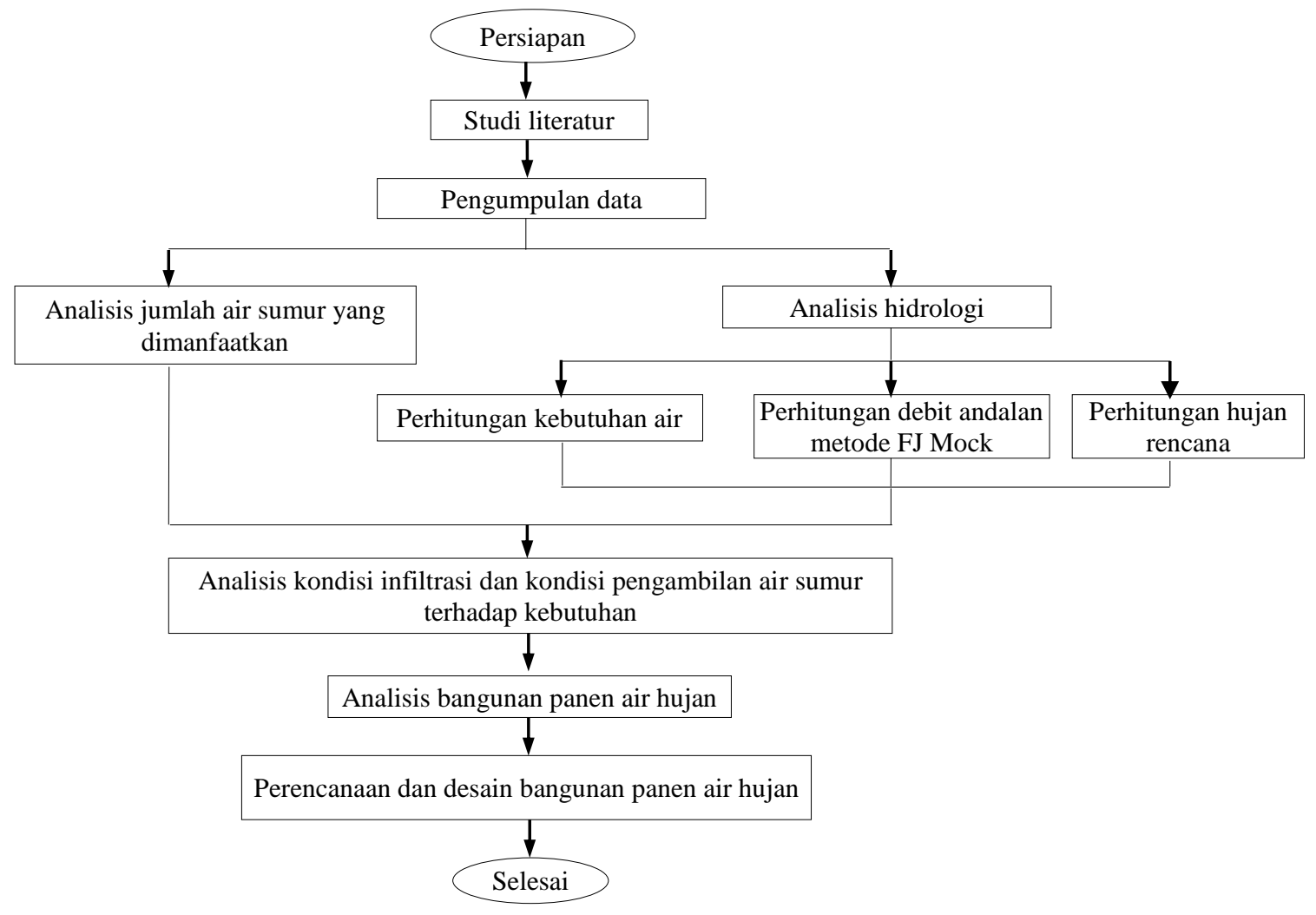

Gambar 1. Bagan alir perencanaan panen air hujan 
Data hujan yang digunakan dalam studi ini adalah data hujan harian selama 10 tahun pada Sta. Gunung Pati, Sta. Ungaran, dan Sta. Pucang Gading.

\section{Perhitungan pengambilan air sumur}

Air sumur yang dimanfaatkan untuk memenuhi kebutuhan pada Kampus Universitas Diponegoro dihitung dengan persamaan (1).

$V d=Q p \times t \times 1$ tahun

dimana :

$\mathrm{Vd}=$ volume besarnya air yang sudah diambil dalam setahun $\left(\mathrm{m}^{3}\right)$

$\mathrm{Qp}=$ kapasitas pompa $\left(\mathrm{m}^{3} / \mathrm{jam}\right)$

$\mathrm{t} \quad=$ lama waktu pengisian (jam)

\section{Analisis hidrologi}

Analisis hidrologi diawali dengan perhitungan kebutuhan air pada Kampus Universitas Diponegoro yang terdiri dari kebutuhan air untuk kampus, kebutuhan fasilitas kampus dan kebutuhan air untuk taman. Perhitungan kebutuhan air sesuai dengan standar perencanaan Ditjen Cipta Karya 1996.

Curah hujan areal dihitung dengan menggunakan metode Polygon Thiessen. Besarnya aliran permukaan dan infiltrasi dihitung menggunakan analisis water balance dengan metode FJ Mock berdasarkan curah hujan bulanan, jumlah hari hujan dan karakteristik daerah pengaliran. Dalam perencanaan panen air hujan dibutuhkan curah hujan rencana yang dihitung menggunakan curah hujan andalan $80 \%$. Data hujan diurutkan dari terkecil hingga terbesar dengan persamaan (2).

$R_{80}=\frac{n}{5}+1$

dimana:

$\mathrm{n} \quad$ = jumlah data curah hujan

Peta lay out Kampus Universitas Diponegoro digunakan untuk mengetahui jenis atap gedung untuk mengetahui koefisien limpasan (k) dan luas daerah tangkapan yang berupa atap. Nilai koefisien $(\mathrm{k})$, curah hujan (R) dan luas daerah tangkapan yang sudah diketahui digunakan untuk menghitung volume air hujan tertampung, dengan persamaan (3).

$\mathrm{V}=\mathrm{R} \times \mathrm{A} \times \mathrm{kV}$

dimana:

$\mathrm{V}=$ volume air tertampung $\left(\mathrm{m}^{3}\right)$

$\mathrm{R}=\operatorname{curah}$ hujan $(\mathrm{m})$

A = luas daerah tangkapan $\left(\mathrm{m}^{3}\right)$

$\mathrm{K}=$ koefisien limpasan air
Dari jumlah volume air hujan yang dapat ditampung kemudian dilakukan perhitungan volume cistern / tampungan yang akan digunakan. Perhitungan volume cistern menggunakan metode simulasi panen air hujan dan metode double mass curve sehingga mendapatkan volume tampungan efektif. Ketika tampungan telah terisi penuh terdapat limpasan air sisa yang kemudian dapat diresapkan melalui sumur resapan yang direncanakan sesuai SNI 03-2453-2002 dengan Persamaan 4, Persamaan 5 dan Persamaan 6.

Volume sumur $\left(\mathrm{V}_{\mathrm{S}}\right)=\frac{1}{4} \times \pi \times \mathrm{D}^{2} \times \mathrm{H}$

Volume resap sumur $(\mathrm{vrsp})=\frac{\text { te }}{24} \times A_{\text {tot }} \times K \ldots \ldots$.

Kapasitas satu sumur $=V_{s}+V_{r s p}$

dimana :

$\mathrm{D}=$ diameter sumur $(\mathrm{m})$

$\mathrm{H}=$ kedalaman sumur $(\mathrm{m})$

$\mathrm{Te}=$ waktu hujan (jam)

$\mathrm{A}=$ luas penampang sumur $\left(\mathrm{m}^{2}\right)$

$\mathrm{K}=$ koefisien permeabelitas

\section{Hasil dan Pembahasan}

\section{Kebutuhan air}

Kebutuhan air pada Kampus Universitas Diponegoro terdiri dari kebutuhan air untuk kampus, kebutuhan air fasilitas kampus dan kebutuhan air taman. Kebutuhan air untuk kampus dihitung berdasarkan jumlah populasi kampus. Kebutuhan air fasilitas kampus dihitung berdasarkan jumlah air yang digunakan pada fasilitas seperti masjid, mushola, kantin dan laboratorium. Kebutuhan air taman dihitung berdasarkan luas area taman. Dari analisis kebutuhan air pada Kampus Universitas Diponegoro dengan prediksi 10 tahun didapatkan hasil seperti disajikan pada tabel berikut:

Tabel 1. Kebutuhan harian rata - rata, maksimal harian dan jam puncak total

\begin{tabular}{ccccc}
\hline No & Tahun & $\begin{array}{c}\text { Rata-rata } \\
\text { (Itr/dtk) }\end{array}$ & $\begin{array}{c}\text { Maks. } \\
\text { harian } \\
\text { (ltr/detik) }\end{array}$ & $\begin{array}{c}\text { Jam } \\
\text { puncak } \\
\text { (ltr/detik) }\end{array}$ \\
\hline 1 & 2014 & 5,920 & 6,808 & 9,955 \\
2 & 2019 & 6,216 & 7,148 & 10,472 \\
3 & 2024 & 6,331 & 7,280 & 10,673 \\
\hline
\end{tabular}

Volume pengambilan air sumur

Kebutuhan air di Universitas Diponegoro dipenuhi dari air tanah dengan pembuatan sumur bor dengan kedalaman yang berkisar antara 65 - 110 meter. Air dari sumur diambil dengan menggunakan pompa yang memiliki spesifikasi yang berbeda yang disesuaikan dengan besarnya jumlah air yang dibutuhkan. 
Tabel 2. Volume pengambilan air sumur

\begin{tabular}{|c|c|c|c|c|c|}
\hline No & Lokasi & Spesifikasi Pompa & $\begin{array}{c}\text { Waktu } \\
\text { penggunaan }\end{array}$ & $\begin{array}{c}\text { Debit } \\
\text { pemompaan }\end{array}$ & $\begin{array}{c}\text { Volume pengambilan } \\
\text { dalam setahun }\left(\mathbf{m}^{\mathbf{3}}\right)\end{array}$ \\
\hline 1 & Teknik Sipil & Grundfos 3 phase & $1,5 \mathrm{jam}$ & $150 \mathrm{lt} / \mathrm{menit}$ & 4860 \\
\hline 2 & Rektorat & Grundfos SP 3 phase & 2 jam & $8 \mathrm{~m}^{3} / \mathrm{jam}$ & 5760 \\
\hline 4 & MIPA & Grundfos type $\mathrm{CH} 2-50$ & $1,5 \mathrm{jam}$ & $2500 \mathrm{l} / \mathrm{jam}$ & 1350 \\
\hline 5 & FKM & Grundfos SA-SPM2 & $1,5 \mathrm{jam}$ & $150 \mathrm{lt} / \mathrm{menit}$ & 4860 \\
\hline 6 & Elektro & Grundfos MR 250 A-Jet & $1,5 \mathrm{jam}$ & $45 \mathrm{l} / \mathrm{menit}$ & 1458 \\
\hline 7 & Gd. Bersama & Aqua jet SP 505 & 1,5 jam & $100 \mathrm{l} / \mathrm{menit}$ & 3240 \\
\hline 8 & Soedarto & Grundfos 3 phase & $1,5 \mathrm{jam}$ & $150 \mathrm{lt} / \mathrm{menit}$ & 4860 \\
\hline 9 & Arsitek, PWK & Shimizu jet pump jet 100 & 2 jam & $50 \mathrm{lt} / \mathrm{min}$ & 2160 \\
\hline 10 & Industri & Shimizu PS 128815 & 1,5 jam & $18 \mathrm{lt} / \mathrm{min}$ & 583,2 \\
\hline 11 & Hukum & Grundfos 3 phase & $1,5 \mathrm{jam}$ & $150 \mathrm{lt} / \mathrm{menit}$ & 4860 \\
\hline 12 & FIB & Grundfos 3 phase & $1,5 \mathrm{jam}$ & $150 \mathrm{lt} / \mathrm{menit}$ & 4860 \\
\hline 13 & FISIP & Grundfos 3 phase & 1,5 jam & $150 \mathrm{lt} / \mathrm{menit}$ & 4860 \\
\hline 14 & Peternakan & Shimizu jet pump jet 100 & 2 jam & $50 \mathrm{lt} / \mathrm{min}$ & 2160 \\
\hline 15 & Mesin & Grundfos 3 phase & $1,5 \mathrm{jam}$ & $150 \mathrm{lt} / \mathrm{menit}$ & 4860 \\
\hline 16 & Kelautan & Aqua jet SP 505 & $1,5 \mathrm{jam}$ & $100 \mathrm{l} / \mathrm{menit}$ & 3240 \\
\hline 17 & Kedokteran & Grundfos 3 phase & $1,5 \mathrm{jam}$ & $150 \mathrm{lt} / \mathrm{menit}$ & 4860 \\
\hline 18 & D3 Teknik & Grundfos SP 3 phase & 2 jam & $8 \mathrm{~m}^{3} / \mathrm{jam}$ & 5760 \\
\hline 19 & FEB & Grundfos 3 phase & $1,5 \mathrm{jam}$ & $150 \mathrm{lt} / \mathrm{menit}$ & 4860 \\
\hline \multicolumn{5}{|c|}{ Total } & 69451 \\
\hline
\end{tabular}

Pompa digunakan dengan durasi pemakaian kurang lebih berkisar antara 1,5 jam hingga 2 jam. Spesifikasi pompa dan besarnya debit pemompaan yang diambil dalam setahun dapat dilihat pada Tabel 2.

Pada Tabel 2 dapat diketahui bahwa besarnya jumlah pengambilan air sumur dalam setahun adalah sebesar $69541 \mathrm{~m}^{3}$ atau sebesar 2,23 lt/dt.

\section{Perencanaan bangunan panen air hujan}

Infiltrasi bulanan dari 2001 hingga 2011 yang disajikan pada Gambar 2.

Dalam grafik tersebut dapat dilihat bahwa nilai infiltrasi cenderung menurun. Nilai air terinfiltrasi pada bulan Januari tahun 2006 sebesar 219,568 mm, selanjutnya untuk bulan Januari tahun berikutnya nilai infiltrasi cenderung turun sampai pada bulan Januari tahun 2011 sebesar 87,223 mm. Pada bulan Maret tahun 2008 nilai infiltrasi sebesar 157,202 $\mathrm{mm}$ dan pada tahun berikutnya untuk bulan yang sama nilai infiltrasi cenderung turun yaitu sebesar 31,205 mm untuk bulan Maret tahun 2011.

Dari perhitungan jumlah air sumur yang dimanfaatkan dapat diketahui bahwa besarnya jumlah pengambilan air sumur dalam setahun adalah sebesar $69.541 \mathrm{~m}^{3}$ atau sebesar 2,23 lt/dtk. Jumlah tersebut lebih besar dari debit optimum pengambilan sumur pada wilayah tembalang yaitu 1,0 lt/dtk (ESDM 2010).

Perencanaan bangunan panen air hujan pada Kampus Universitas Diponegoro dibagi kedalam 18 zona. Letak bangunan panen air hujan direncanakan pada tiap zona dan dapat dilihat pada Gambar 3.

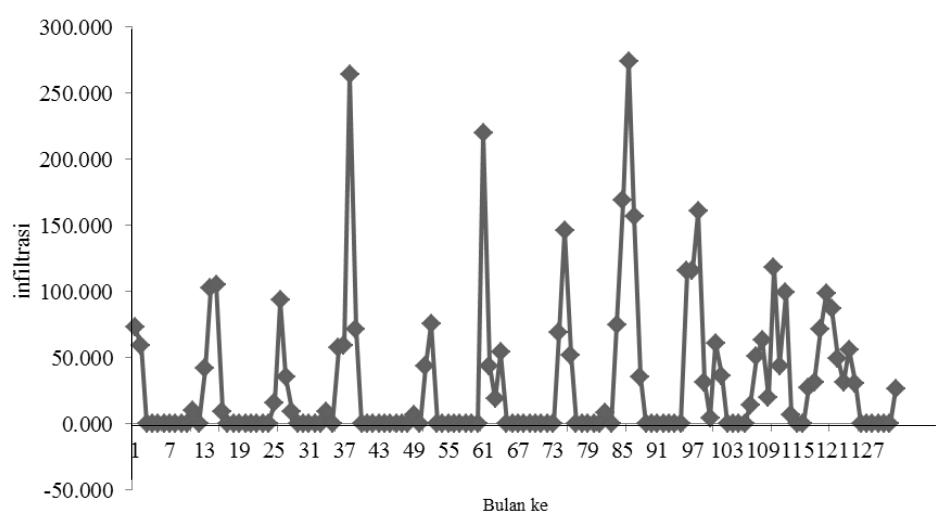

Gambar 2. Grafik infiltrasi bulanan tahun 2001 - 2011 


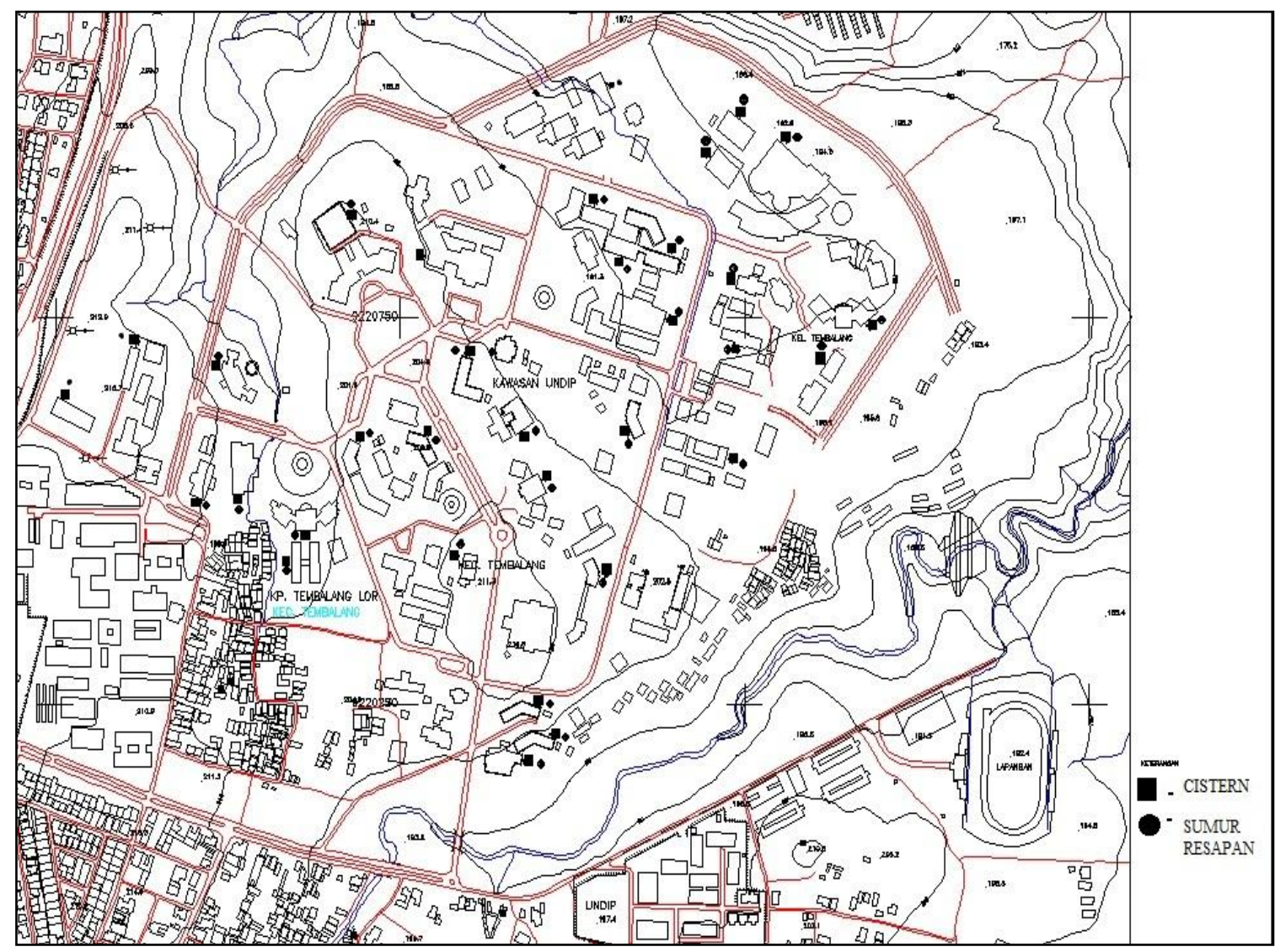

Gambar 3. Plotting bangunan panen air hujan Kampus Universitas Diponegoro

Tabel 3. Volume air hujan yang dapat ditampung pada kampus Universitas Diponegoro

\begin{tabular}{|c|c|c|c|c|c|c|c|c|c|c|c|c|c|c|}
\hline \multirow{2}{*}{ Zona } & \multirow{2}{*}{ Gedung } & \multirow{2}{*}{$\begin{array}{c}\text { Luas } \\
\text { gedung } \\
\left(\mathbf{m}^{2}\right)\end{array}$} & \multicolumn{12}{|c|}{ Besar curah hujan perbulan yang bisa ditampung $\left(\mathrm{m}^{3}\right)$} \\
\hline & & & Jan & Feb & Mar & Apr & May & Jun & Jul & Aug & Sep & Oct & Nov & Dec \\
\hline \multirow[t]{2}{*}{1} & Teknik Sipil & 4209 & 600 & 679 & 638 & 480 & 206 & 97 & 1 & 0 & 0 & 117 & 401 & 429 \\
\hline & Gd. Pertamin & 610 & 75 & 85 & 80 & 60 & 26 & 12 & 0 & 0 & 0 & 15 & 50 & 54 \\
\hline 2 & Arsitek, Industri, PWK & 5098 & 727 & 822 & 772 & 581 & 249 & 118 & 1 & 0 & 0 & 142 & 486 & 519 \\
\hline 3 & FISIP & 1520 & 217 & 245 & 230 & 173 & 74 & 35 & 0 & 0 & 0 & 42 & 145 & 155 \\
\hline 4 & Hukum & 6876 & 849 & 961 & 903 & 679 & 291 & 138 & 1 & 0 & 0 & 166 & 568 & 607 \\
\hline 5 & Ilmu & 1500 & 185 & 210 & 197 & 148 & 64 & 30 & 0 & 0 & 0 & 36 & 124 & 132 \\
\hline 6 & Widy & 5355 & 763 & 863 & 811 & 610 & 262 & 124 & 1 & 0 & 0 & 149 & 510 & 546 \\
\hline 7 & Rek & 5100 & 727 & 822 & 773 & 581 & 249 & 118 & 1 & 0 & 0 & 142 & 486 & 520 \\
\hline 8 & & 5790 & 825 & 933 & 877 & 660 & 283 & 134 & 1 & 0 & 0 & 161 & 552 & 590 \\
\hline 9 & MIP & 10365 & 477 & 1671 & 1570 & 1181 & 507 & 240 & 2 & 0 & 0 & 288 & 987 & 1056 \\
\hline 10 & Ked & 8718 & 1077 & 1218 & 1145 & 861 & 369 & 175 & 1 & 0 & 0 & 210 & 720 & 770 \\
\hline 11 & Psik & 4644 & 662 & 749 & 703 & 529 & 227 & 107 & 1 & 0 & 0 & 129 & 442 & 473 \\
\hline 12 & Kela & 4483 & 639 & 723 & 679 & 511 & 219 & 104 & 1 & 0 & 0 & 125 & 427 & 457 \\
\hline 13 & Mesin & 2065 & 294 & 333 & 313 & 235 & 101 & 48 & 0 & 0 & 0 & 57 & 197 & 210 \\
\hline 14 & Elektro & 1769 & 252 & 285 & 268 & 202 & 87 & 41 & 0 & 0 & 0 & 49 & 169 & 180 \\
\hline 15 & Kimia, Soe & 5740 & 818 & 925 & 870 & 654 & 281 & 133 & 1 & 0 & 0 & 159 & 547 & 585 \\
\hline 16 & Peter & 5515 & 786 & 889 & 835 & 629 & 270 & 127 & 1 & 0 & 0 & 153 & 525 & 562 \\
\hline 17 & D3 Teknik & 9335 & 1331 & 1505 & 1889 & 1064 & 457 & 216 & 1 & 0 & 0 & 259 & 889 & 951 \\
\hline 18 & $\begin{array}{l}\text { Dekanat Teknik, gd. } \\
\text { Bersama }\end{array}$ & 3687 & 526 & 594 & 559 & 420 & 180 & 85 & 1 & 0 & 0 & 102 & 351 & 376 \\
\hline
\end{tabular}


Selanjutnya perencanaan panen air hujan dimulai dengan perhitungan volume air hujan yang dapat ditampung. Volume air hujan yang dapat ditampung pada Kampus Universitas Diponegoro di Zona 14 sebesar $1533 \mathrm{~m}^{3} /$ tahun dan untuk zona perencanaan lain disajikan pada Tabel 3.

Sistem panen air hujan direncanakan pada zona 14 dengan volume tampungan yang digunakan adalah sebesar $240 \mathrm{~m}^{3}$. Tampungan tersebut dapat memenuhi kebutuhan air selama 8 bulan atau $75 \%$ bulan dalam setahun. Untuk strruktur tampungan digunakan beton bertulang dan direncanakan didalam tanah.

Perencanaan sumur resapan didesain sesuai volume limpasan maksimum harian yang didapat dari simulasi panen air hujan. Besarnya volume maksimum limpasan harian yaitu sebesar 40,05 $\mathrm{m}^{3}$. Dengan waktu pengaliran rencana 24 jam dan laju permeabilitas sebesar $3,2184 \mathrm{~cm} / \mathrm{jam}$ atau 0,77 $\mathrm{m}$ per hari dan waktu hujan efektif 2 jam, maka dapat dihitung:

$$
\begin{aligned}
\text { Volume sumur }\left(\mathrm{V}_{\mathrm{S}}\right) & =\frac{1}{4} \times \pi \times \mathrm{D}^{2} \times \mathrm{H} \\
& =\frac{1}{4} \times \pi \times 1.5^{2} \times 3 \\
& =5,29 \mathrm{~m}^{3}
\end{aligned}
$$

Volume resap sumur (vrsp) $=\frac{\text { te }}{24} \times A_{\text {tot }} \times K$

$$
\begin{aligned}
& =\frac{2}{24} \times 15,91 \times 0,77 \\
& =1,02 \mathrm{~m}
\end{aligned}
$$

Sehingga,

$$
\begin{aligned}
\text { Kapasitas satu sumur } & =V_{s}+V_{r s p} \\
& =6,32 \mathrm{~m}^{3}
\end{aligned}
$$

Jumlah sumur yang diperlukan $=\frac{\text { Volume maksimal }}{\text { Kapasitas satu sumur }}$

$$
\begin{aligned}
& =\frac{40,03}{6,32} \\
& =6,33 \approx 7 \text { buah }
\end{aligned}
$$

Detail bangunan panen air hujan di Zona 14 dapat dilihat pada Gambar 4 dan Gambar 5.

Tiap zona memiliki jenis bangunan panen air hujan yang berbeda. Jenis sistem bangunan panen hujan tiap zona berbeda diakibatkan oleh jumlah volume air yang dapat ditampung yang berbeda dan volume limpasan harian yang berbeda pula. Jenis bangunan panen air hujan tiap zona di sajikan Tabel 4

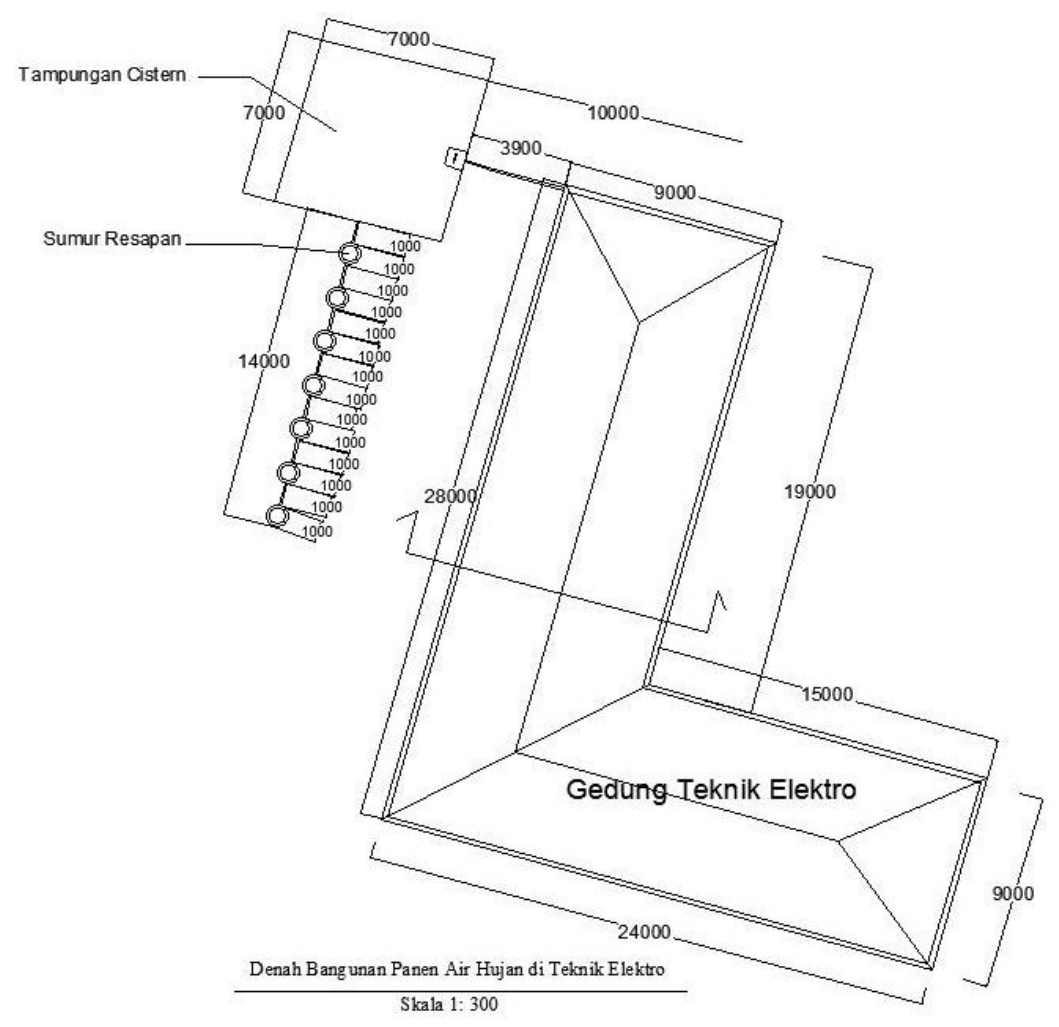

Gambar 4. Denah bangunan panen air hujan di Teknik Elektro 


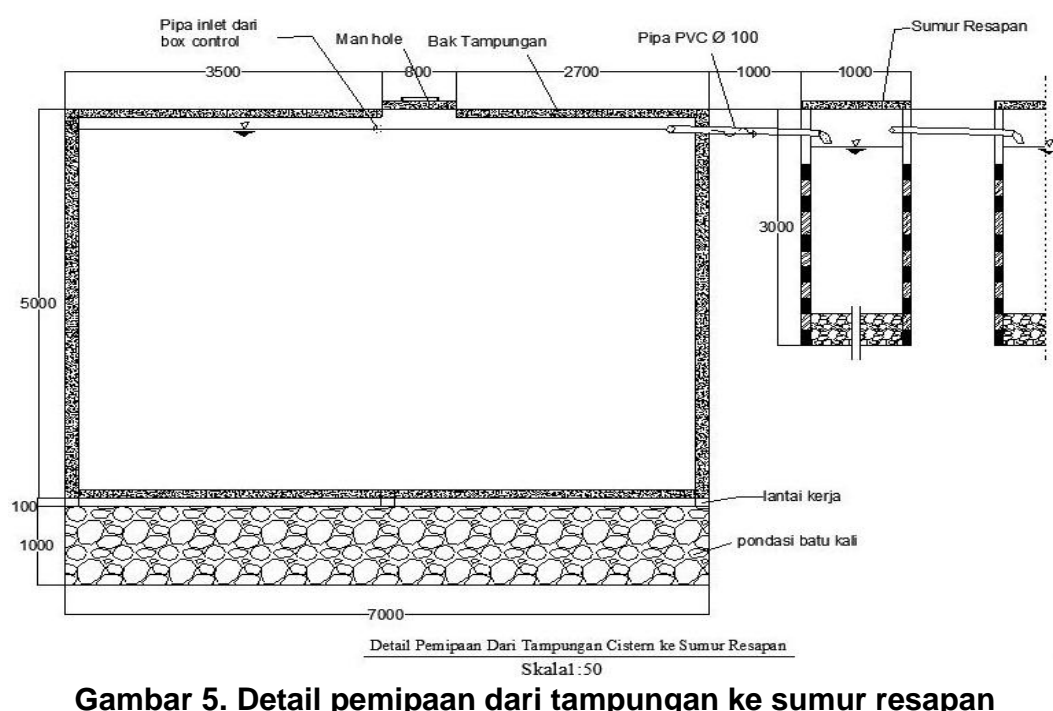

Tabel 4. Jenis bangunan panen air hujan tiap zona perencanaan pada Kampus Universitas Diponegoro

\begin{tabular}{clcl}
\hline Zona & \multicolumn{1}{c}{ Wilayah gedung } & Jenis & Dimensi \\
\hline 1 & Teknik Sipil, gd. Pertamina & Tipe 1 & 1 cistern $240 \mathrm{~m}^{3}$, sumur resapan \\
2 & Arsitek, Industry, PWK & Tipe 2 & 2 cistern $240 \mathrm{~m}^{3}$, sumur resapan \\
3 & FISIP & Tipe 1 & 1 cistern $240 \mathrm{~m}^{3}$, sumur resapan \\
4 & Fakultas Hukum & Tipe 2 & 3 cistern $240 \mathrm{~m}^{3}$, sumur resapan \\
5 & Fakultas Ilmu Budaya & Tipe 1 & 1 cistern $240 \mathrm{~m}^{3}$, sumur resapan \\
6 & Gedung Widya Puraya & Tipe 2 & 1 cistern $240 \mathrm{~m}^{3}$, sumur resapan \\
7 & Gedung Rektorat & Tipe 1 & 1 cistern $240 \mathrm{~m}^{3}$, sumur resapan \\
8 & Fakultas Ekonomi dan Bisnis & Tipe 2 & 2 cistern $240 \mathrm{~m}^{3}$, sumur resapan \\
9 & MIPA & Tipe 2 & 4 cistern $240 \mathrm{~m}^{3}$, sumur resapan \\
10 & Kedokteran & Tipe 2 & 5 cistern $240 \mathrm{~m}^{3}$, sumur resapan \\
11 & Psikologi & Tipe 1 & 2 cistern $240 \mathrm{~m}^{3}$, sumur resapan \\
12 & Kelautan dan Perikanan & Tipe 1 & 1 cistern $240 \mathrm{~m}^{3}$, sumur resapan \\
13 & Teknik Mesin & Tipe 1 & 1 cistern $240 \mathrm{~m}^{3}$, sumur resapan \\
14 & Teknik Elektro & Tipe 1 & 1 cistern $240 \mathrm{~m}^{3}$, sumur resapan \\
15 & Teknik Kimia, gd. Sudarto & Tipe 1 & 1 cistern $240 \mathrm{~m}^{3}$, sumur resapan \\
16 & Peternakan, Pertanian & Tipe 2 & 5 cistern $240 \mathrm{~m}^{3}$, sumur resapan \\
17 & D3 Teknik & Tipe 2 & 2 cistern $240 \mathrm{~m}^{3}$, sumur resapan \\
18 & Gedung Bersama, Dekanat Teknik & Tipe 1 & 2 cistern $240 \mathrm{~m}^{3}$ sumur resapan \\
\hline
\end{tabular}

Tabel 5. Pemanfaatan air panen air hujan di Kampus Universitas Diponegoro

\begin{tabular}{lcccccc}
\hline Bulan & $\begin{array}{c}\text { Kebutuhan } \\
\text { air rata- } \\
\text { rata tiap } \\
\text { bulan }\left(\mathbf{m}^{\mathbf{3}}\right)\end{array}$ & $\begin{array}{c}\text { Kebutuhan air } \\
\text { taman dan } \\
\text { kantin tiap } \\
\text { bulan }\left(\mathbf{m}^{\mathbf{3}}\right)\end{array}$ & $\begin{array}{c}\text { Pemanfaatan } \\
\text { air sumur tiap } \\
\text { bulan } \\
\left(\mathbf{m}^{\mathbf{3}}\right)\end{array}$ & $\begin{array}{c}\text { Air hujan } \\
\text { yang dapat } \\
\text { ditampung } \\
\left(\mathbf{m}^{\mathbf{3}}\right)\end{array}$ & $\begin{array}{c}\text { Volume air } \\
\text { hujan yang } \\
\text { dimanfaatkan } \\
\left(\mathbf{m}^{\mathbf{3}}\right)\end{array}$ & $\begin{array}{c}\text { Volume } \\
\text { Air sisa yang } \\
\text { diresapkan } \\
\left(\mathbf{m}^{\mathbf{3}}\right)\end{array}$ \\
\hline Januari & 15344,6 & 2750 & 5780,1 & 12832 & 4320 & 8512 \\
Februari & 15344,6 & 2750 & 5780,1 & 14511 & 4320 & 10191 \\
Maret & 15344,6 & 2750 & 5780,1 & 14111 & 4320 & 9791 \\
April & 15344,6 & 2750 & 5780,1 & 10261 & 4320 & 5941 \\
Mei & 15344,6 & 2750 & 5780,1 & 4402 & 4320 & 82 \\
Juni & 15344,6 & 2750 & 5780,1 & 2080 & 2080 & 0 \\
Juli & 15344,6 & 2750 & 5780,1 & 13 & 0 & 0 \\
Agustus & 15344,6 & 2750 & 5780,1 & 0 & 0 & 0 \\
September & 15344,6 & 2750 & 5780,1 & 0 & 0 & 0 \\
Oktober & 15344,6 & 2750 & 5780,1 & 2501 & 2501 & 0 \\
November & 15344,6 & 2750 & 5780,1 & 8576 & 4320 & 4256 \\
Desember & 15344,6 & 2750 & 5780,1 & 9173 & 4320 & 4853 \\
\hline
\end{tabular}


Bangunan panen air hujan juga dilengkapi dengan perencanaan taman resapan dan jalan resapan untuk meresapkan air lebih efektif. Dari perhitungan taman resapan dan jalan resapan diketahui bahwa jalan resapan mampu meresapkan air sebesar $960.279,7 \mathrm{~m}^{3}$ dalam setahun dan untuk taman resapan meresapkan air sebesar 425.663,7 $\mathrm{m}^{3}$.

Dari perhitungan simulasi panen air hujan didapatkan volume air yang dapat dipanen sebesar $78461 \mathrm{~m}^{3}$, volume air yang ditampung untuk dimanfaatkan sebesar $33000 \mathrm{~m}^{3}$ dan volume air diresapkan oleh sumur resapan sebesar $45461 \mathrm{~m}^{3}$ dan disajikan oleh Tabel 5.

Dari hasil air yang dapat diresapkan oleh sumur resapan, taman resapan dan jalan resapan dibandingkan dengan potensi curah hujan wilayah Universitas Diponegoro, maka didapatkan bahwa pembangunan bangunan tersebut dapat meresapkan air hujan sebesar $51 \%$ dari total potensi hujan tersebut. Penggunaan panen air hujan juga mengembalikan pengambilan air sumur menjadi normal pada kondisi debit pengambilan optimum. Hasil perhitungan rencana anggaran dan biaya, perencanaan bangunan panen air hujan pada kawasan Universitas Diponegoro Tembalang memakan biaya sebesar Rp. 275.465.000,- dengan proses pekerjaan selama 29 hari.

\section{Kesimpulan}

Dari hasil analisis data dan pembahasan dapat ditarik kesimpulan sebagai berikut:

1. Hasil perhitungan kebutuhan air pada wilayah Kampus Universitas Diponegoro pada tahun 2014 adalah sebesar 5,920 lt/dt untuk kebutuhan air rata-rata, 6,808 lt/dt untuk kebutuhan maksismal harian, dan 9,955 lt/dt untuk kebutuhan pada jam puncak.

2. Besarnya volume pemakaian air tanah pada wilayah Kampus Universitas Diponegoro pada tahun 2014 adalah sebesar $29.541 \mathrm{~m}^{3}$ atau sebesar 2,23 lt/dt.

3. Dari simulasi panen air hujan didapatkan volume air yang dapat dipanen sebesar 78.461 $\mathrm{m}^{3}$, volume air yang ditampung untuk dimanfaatkan sebesar $33.000 \mathrm{~m}^{3}$ dan volume air yang diresapkan oleh sumur resapan sebesar $45.461 \mathrm{~m}^{3}$.

\section{Daftar Pustaka}

Aji Aflakhi, Venni Budi Cahyani, Dwi Kurniani, Hary Budieny, 2014. Perencanaan Eko-Drainase Kawasan Perumahan Tembalang Pesona Asri Semarang, Jurnal Karya Teknik Sipil Vol.3.

Asdak, Chay, 2002. Hidrologi dan Pengelolaan Daerah Aliran Sungai, Jakarta.

Badan Standarisasi Nasional, 1996. SNI 03-06911996, Paving Block atau Bata Beton, Jakarta.

Badan Standarisasi Nasional, 2002. SNI 03-24532002 tentang Tata Cara Perencanaan Sumur Resapan Air Hujan untuk Lahan Pekarangan, Jakarta.

Departemen Energi dan Sumber Daya Mineral, 2010. CAT Wilayah Semarang, Semarang.

Direktorat Jendral Cipta Karya, 2007. Petunjuk Teknis Pelaksanaan Prasarana Air Minum Sederhana, Jakarta.

Govt. of India consultancy servise organization, 2002. Rainwater Harversting and Conservation Manual, New Delhi.

Kementrian Pekerjaan Umum Dirjen Cipta Karya, 2013. Katalog Infrastruktur Bidang Cipta Karya yang Potensial, Jakarta.

Mori, Kiyotaka dkk., 1999. Hidrologi Untuk Pengairan, Jakarta.

Sri Sangkawati, Sugiyanto, Hary Budieny, 2013. Perkiraan Koefisien Karakteristik Daerah Aliran Sungai Krengseng untuk Membangun Kurva Durasi Debit, Jurnal Media Komunikasi Teknik Sipil Vol.19 no 1.

Tim Dosen Pengampu, 2005. Diktat Pengembangan Sumber daya Air, Teknik Sipil Universitas Diponegoro, Semarang.

Waterfall, Patricia H, 2006. Rainwater Harversting for Landscape Use, University of Arizona.

Worm, Janette, Tim Van hattum, 2006. Rainwater Harversting for Domestic Use, Netherlands.

Wynkoop, Samuel E., Jr., 2010. Low Impact Development National Manual, Maryland. 